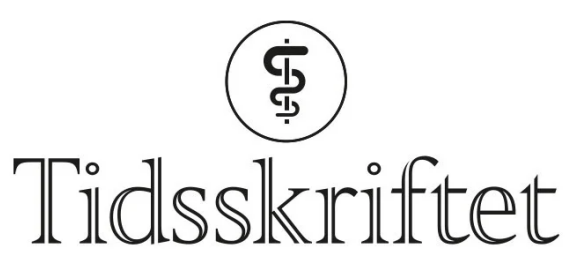

DEN NORSKE LEGEFORENING

\title{
Velskrevet og tankevekkende
}

\author{
ANMELDELSER
}

BERNHARD WEIDLE

Barne- og ungdomspsykiatrisk klinikk

St. Olavs hospital

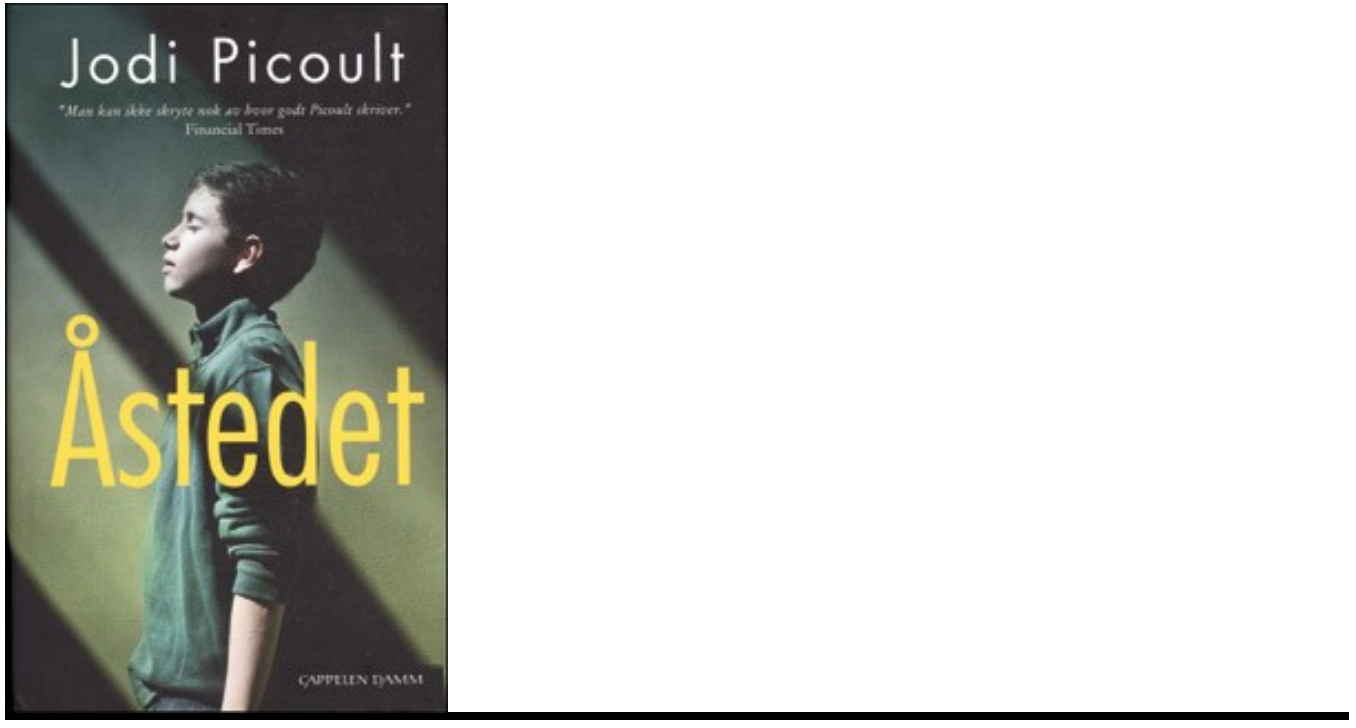

Picoult, Jodi

Åstedet

619 s. Oslo: Cappelen Damm, 2011. Pris NOK 349

ISBN 978-82-02-33515-1

Boken er roman nr. 17 av den amerikanske bestselgerforfatteren Jodi Picoult (f. 1966). Hun belyser ofte kontroversielle temaer, bl.a. skolemassakrer, selvmord blant ungdom, vold i familien, organtransplantasjon og overgrep. Også i denne romanen bruker hun en fortellerteknikk der samme hendelsesforløp beskrives fra de ulike protagonistenes perspektiv. 
I Åstedet blir vi kjent med alenemoren Emma, hennes to sønner, en etterforsker og en advokat som Emma engasjerer etter hvert. Emmas eldste sønn Jakob har diagnosen Aspergers syndrom - med åstedsgransking og rettsmedisin som sin særinteresse. Sønnen abonnerer på rettsmedisinske fagtidsskrifter og må hver dag følge med på TV-serien Crime busters. Han konkurrerer med TV-etterforskerne om hvem som klarer å løse saken raskest. Hver gang skriver han omhyggelig notater, selv om han har sett programmet tidligere og kan plottet og detaljene utenat. I tillegg elsker han å lage krimgåter som moren må løse. Historien tar en dramatisk vending da Jakobs støttekontakt og hjelpelærer blir funnet drept, og mistanken rettes mot Jakob.

Picoult skal ha all ære for å bruke sin status som berømt forfatter, til å ta opp temaet Aspergers syndrom og formidle det til et publikum som ellers ikke ville komme i kontakt med denne informasjonen. Boken er velskrevet og spennende dersom man lar seg dra inn i dramatikken rundt kulturkollisjonen mellom Jakobs kommunikasjonsmåte og et rettssystem som ikke skjønner et individ som tenker og handler radikalt annerledes. Forfatteren formidler Jakobs tenke- og væremåte og vekker vår sympati for både ham og hans oppofrende mamma. Hun gir en innsiktsfull skildring av hvordan Jakobs behov påvirker hele familien.

For en leser som ikke er fortrolig med denne diagnosen, gir hun god informasjon med mange illustrerende eksempler pakket inn i en spennende kontekst. Dette er bokens sterkeste side, men samtidig blir det en svakhet for den som leser den hovedsakelig som en kriminalroman. Da blir historien preget av noen mindre troverdige, tilfeldige sammentreff, og man lurer på hvorfor sannheten ikke kom frem tidligere. Til plottets forsvar kan man kanskje si at ubevisst var hovedpersonene så redd for sannheten at de ikke ville høre den, men det mest sannsynlige svaret er at da hadde boken vært slutt etter forholdsvis få sider.

Er romanfiguren Jakob troverdig som en ungdom med Aspergers syndrom? Picoult har arbeidet som lærer, og hennes pedagogiske intensjon preger boken på godt og vondt. På samme måte som romanens hovedfigur, har også forfatteren grundig etterforsket bakgrunnsmaterialet. I etterordet forteller hun at hun har gjennomført tallrike samtaler med ungdommer med Aspergers syndrom, deres foreldre og fagfolk. En ungdom med diagnosen hun hadde intervjuet, fungerte som «konsulent» og gikk gjennom manuskriptet for å rette opp feil og usannsynligheter i beskrivelsen av Jakob.

Likevel virker Jakob mer som et pedagogisk eksempel enn en virkelig ungdom. Han blir til tider noe oppkonstruert og klisjéaktig med alle sine autistiske trekk. Av og til likner symptomportrettet på en miks mellom klassisk autisme og Aspergers syndrom, men den typen diagnostiske avgrensninger diskuteres for så vidt også i fagfeltet. Også kunstgrepet med å la Jakob presentere sitt perspektiv virker en del ganger mer pedagogisk motivert enn reelt. Men eksemplene er i og for seg velvalgte og både illustrerende og underholdende. Fra et norsk perspektiv virker beskrivelsen av guttens hverdag, mellom dietter, kosttilskudd, diverse alternative terapier og privat betalte leksjoner med sosial trening, å være noe preget av hovedpersonens nordamerikanske bakgrunn.

En ting som er direkte irriterende, er fremstillingen av diskusjonen om hvorvidt vaksiner kan forårsake autisme. Riktignok prøver forfatteren å balansere informasjonen med å beskrive argumenter både for og imot teorien. Hun gir et sammendrag om kontroversen om at tiomersal som konserveringsmiddel i vaksiner, kan ha bidratt til den $\emptyset$ kende forekomsten av autisme. Hun siterer også motargumentene i form av fem store epidemiologiske studier hvor man ikke fant noen sammenheng mellom vaksine og autisme, i tillegg til at autismeforekomsten fortsatt er økende, selv om de aktuelle vaksinene nå er uten tiomersal. Likevel lar hun Emma beskrive hvordan hennes sønn var en 
vanlig toåring inntil han fikk vaksinene, og at hun ikke tror at det var en tilfeldig forbindelse. Sannsynligvis for politisk korrekthets skyld legger Emma til at etter hennes oppfatning er fordelene med vaksinering fortsatt større enn risikoen.

Oversettelsen må ha vært krevende. De mange eksemplene med bokstavelig tolkning av uttrykk med overført betydning som er karakteristisk for mennesker med Aspergers syndrom, er ikke lett å gjengi på norsk. Stort sett fungerer oversettelsen bra, selv om den halter litt. «The low end of the autism spectrum» er blitt til «den ytre delen av autismespekteret», noe som er et uvanlig begrep og ikke det samme. En skjemmende feil er at haemophilus influenzae type b i oversettelsen er blitt til blødersykdommen hemofili B.

Boken kan vekke interesse og sympati for mennesker med Aspergers syndrom. Dette formålet understrekes i den engelske originalteksten der det følger med et appendiks («reading guide») med tips om videre lesning og utdypende spørsmål om temaer som tas opp i teksten. Som et nyttig bidrag til å øke forståelsen for mennesker med autismespektertilstander, er dette en roman jeg ønsker mange vil lese.

Publisert: 13. desember 2011. Tidsskr Nor Legeforen. DOI: 10.4045/tidsskr.11.0845

(C) Tidsskrift for Den norske legeforening 2023. Lastet ned fra tidsskriftet.no 26. april 2023. 